\title{
Hubungan morfologi telur dengan bobot telur dan bobot DOC dengan bobot badan ayam Kampung F1
}

\section{The relationship between egg morphology with egg weight and DOC weight with body weight of Kampung F1}

\section{Redo Prawira $^{1}$, Depison $^{1 *}$, Gushariyanto ${ }^{1}$, Silvia Erina ${ }^{1}$}

${ }^{1}$ Program Studi Peternakan, Fakultas Peternakan, Universitas Jambi. Jl, Jambi-Ma, Bulian KM. 15 Mendalo, Indah Jambi 36361 Indonesia

*Email Koresponden: depison.nasution@unja.ac.id

\begin{tabular}{|c|c|}
\hline ARTICLE INFO & A B S T R A K \\
\hline Received: & \multirow{9}{*}{$\begin{array}{l}\text { Penelitian ini bertujuan untuk mengetahui hubungan antara morfologi telur dengan } \\
\text { bobot telur dan bobot DOC dengan bobot badan ayam Kampung F1. Materi penelitian } \\
\text { yaitu } 174 \text { ayam Kampung yang berasal dari penetasan } 315 \text { butir telur. Metode yang } \\
\text { digunakan adalah metode eksperimen. Data yang dihimpun: ukuran telur, bobot telur, } \\
\text { bobot badan, pertambahan bobot badan serta ukuran tubuh. Data ukuran telur, bobot } \\
\text { telur, bobotbadan, pertambahan bobotbadan dan ukuran tubuh dianalisis menggunakan } \\
\text { uji-t. Hubungan antara variabel dianalisis regresi dan korelasi. Penciri ukuran dan } \\
\text { bentuk tubuh dianalisis menggunakan analisis komponen utama. Hasil penelitian } \\
\text { menunjukan ukuran telur, bobot telur, bobot badan, pertambahan bobot badan serta } \\
\text { ukuran tubuh ayam Kampung jantan berbeda (P<0,05) lebih tinggi dari betina. Ukuran } \\
\text { telur berpengaruh terhadap bobot telur, dan bobot DoC berpengaruh terhadap bobot } \\
\text { badan umur } 4,8 \text {, dan } 12 \text { minggu. Ukuran telur berkolerasi positif dengan bobot telur } \\
\text { jantan dan betina. Bobot DoC berkolerasi positif dengan bobot badan ayam kampung } \\
\text { umur } 4,8 \text {, dan } 12 \text { minggu. Korelasi yang paling erat antara ukuran telur dengan bobot } \\
\text { telur adalah lingkar telur ( } 0,913) \text {, dan bobot DoC dengan bobot badan adalah bobot } \\
\text { umur } 4 \text { minggu }(0,936) \text {. Kesimpulan, hubungan ukuran telur dengan bobot telur dan } \\
\text { bobot DoC dengan bobot badan berbentuk linier dan bernilai positif. }\end{array}$} \\
\hline 7 July 2021 & \\
\hline & \\
\hline $\begin{array}{l}\text { Published: } \\
31 \text { October } 2021\end{array}$ & \\
\hline Kata kunci: & \\
\hline Ayam Kampung & \\
\hline Bobot telur & \\
\hline Ukuran telur & \\
\hline Bobot badan & \\
\hline
\end{tabular}

A B S T R A C T

This study aims to determine the relationship between egg morphology and egg weight and DOC weight with body weight of Kampung F1 chickens. The research material was 174 free-range chickens from hatching 315 eggs. The method used: experimental method. Data collected: egg size, egg weight, body weight, body weight gain, and body size. Data on egg size, egg weight, body weight, body weight gain and body size were analyzed using a t-test. The relationship between variables was analyzed regression and correlation analysis. Characteristics of body size and shape were analyzed principal component analysis. The results showed that egg size, egg weight, body weight, body weight gain and body size of male Kampung chickens were different $(P<0.05)$ higher than females. Egg size affects egg weight, and DOC weight affects body weight at 4, 8, and 12 weeks of age. Egg size was positively correlated with male and female egg weights. DOC weight was

Key words: Kampung chicken Egg weight Egg measurements Body weight positively correlated with body weight of Kampung chickens aged 4, 8, and 12 weeks. The closest correlation between egg size and egg weight was egg circumference (0.913), and DOC weight with body weight was weight at 4 weeks of age (0.936). In conclusion, the relationship between egg size and egg weight, DOC weight and body weight were linear and had appositive values. 


\section{PENDAHULUAN}

Ayam lokal adalah ayam asli Indonesia maupun yang berasal dari luar Indonesia, yang telah beradaptasi dan berkembang biak dengan baik di Indonesia. Ayam lokal memiliki peran yang sangat penting dalam kehidupan masyarakat pedesaan yaitu sebagai sumber pendapatan. Ayam lokal juga bermanfaat sebagai sumber daya genetik yang sangat berharga dalam pemuliaan ternak, sehingga perlu untuk dilestarikan dan dikembangkan. Indonesia memiliki 32 galur ayam lokal yang salah satunya yaitu ayam Kampung.

Ayam Kampung (Galus galus domesticus) merupakan salah satu jenis dari ayam lokal yang banyak dipelihara oleh masyarakat Indonesia, namun belum memiliki karakteristik khusus dibandingkan beberapa jenis ayam lokal lainnya (Irmaya, Gushairiyanto, \& Depison, 2021). Pemeliharaan ayam Kampung tidak membutuhkan lahan yang luas, penyediaan pakan mudah dan murah sehingga lebih cepat dirasakan manfaat ekonominya (Nuraini, Hidayat, \& Yolanda, 2018). Namun, ayam Kampung memiliki kelemahan seperti produktivitas umumnya rendah, sehingga perlu dilakukan upaya untuk peningkatkan produktivitas melalui seleksi.

Seleksi adalah suatu proses memilih ternak yang di anggap memiliki mutu genetik yang lebih baik untuk dikembangkan. Seleksi juga merupakan dasar utama pemuliaan ternak yang dilakukan untuk meningkatkan dan memperbesar peluang memperoleh mutu genetik menjadi lebih baik (Okatama, Maylinda \& Nurgiartiningsih, 2018). Seleksi dapat dilakukan melalui bobot telur, ukuran telur, bobot DOC, bobot badan, pertambahan bobot badan serta ukuran tubuh.

Bobot telur adalah nilai berat telur yang pengukurannya dilakukan dengan cara penimbangan (Lestari, Ismoyowati, \& Sukardi, 2013). Pengukuran telur adalah suatu indikasi untuk mengetahui tingkat kelonjongan atau bulatnya bentuk telur (Badaruddin et. al., 2017). Bobot DOC adalah bobot yang diperoleh dari hasil penimbangan anak ayam yang menetas setelah bulu anak ayam tersebut kering dalam kurun waktu 24 jam (Lestari et al., 2013).

Bobot telur, ukuran-ukuran telur, bobot DOC diduga memiliki hubungan positif dan signifikan (Okatama et al., 2018). Semakin berat bobot telur diduga akan menghasilkan bobot DOC yang semakin berat (Yuniarinda, Edy, \& Sri, 2019).
Bobot DOC dengan bobot badan ayam Kampung diduga mempunyai hubungan yang sangat nyata dan sangat tinggi, semakin besar bobot DOC maka bobot badan akan semakin besar (Rajab, 2013). Menurut Wardono, Sugihono, Kusnadi \& Suprijono (2014) bobot DOC diduga memiliki hubungan dengan bobot badan dan pertambahan bobot badan ayam Kampung.

Berdasarkan uraian di atas diduga adanya hubungan antara ukuran telur dengan bobot telur dan bobot DOC dengan bobot badan ayam Kampung jantan dan betina, untuk itu perlu dilakukan penelitian mengenai hubungan ukuran telur dengan bobot telur dan bobot DOC dengan bobot badan ayam Penelitian ini bertujuan untuk mengetahui hubungan antara morfologi telur dengan bobot telur dan bobot DOC dengan bobot badan ayam Kampung F1.

\section{MATERI DAN METODE}

\section{Materi}

Materi penelitian ini adalah 315 butir telur dan 174 ekor ayam Kampung yang diperoleh dari tetua (G0). Komposisi pakan BR1 untuk periode starter ayam umur 1 sampai 21 hari dan pakan BR2 untuk ayam umur 22 sampai 90 hari dapat dilihat lebih jelas pada Tabel 1, vaksin dan obatobatan. Peralatan yang digunakan adalah alat tulis, jangka sorong digital, timbangan digital kapasitas $3 \mathrm{~kg}$ dengan ketelitian 0,1 g, kamera digital, pita ukur, lampu pijar, tempat pakan, tempat minum, serta mesin tetas.

Tabel 1. Komposisi pakan BR1 dan BR2

\begin{tabular}{lcc}
\hline Kandungan Nutrisi & BR1 & BR2 \\
\hline Energi (kkal/kg) & 4100 & 4100 \\
Protein (\%) & 21 & 19 \\
Lemak (\%) & 3-Jul & $3-8$ \\
Kalsium (\%) & $0,9-1,1$ & $0,9-1,1$ \\
Pospor (\%) & $0,6-0,9$ & $0,6-0,9$ \\
\hline
\end{tabular}

\section{Metode}

Metode yang digunakan adalah metode eksperimen melalui pengamatan secara langsung terhadap penetasan telur dan pemeliharaan ayam Kampung. Data yang dihimpun meliputi bobot telur, bobot tetas, bobot badan, pertambahan bobot badan serta ukuran ukuran tubuh ayam Kampung generasi pertama. Proses pembentukan generasi pertama (F1) yaitu dengan cara seleksi 
indukan F0 sebesar $20 \%$ jantan dan 36\% betina, sehingga diperoleh indukan sebanyak 10 ekor jantan dan 36 ekor betina. Ayam yang telah diseleksi dipelihara sampai mengahasilkan telur dengan rasio jantan dan betina 1:6. Telur dikumpulkan selama 12 hari, setiap 6 hari telur yang terkumpul ditimbang kemudian diberi tanda $(\mathrm{A}, \mathrm{B}, \mathrm{C})$ dengan menggunakan spidol untuk memudahkan proses pemutaran telur saat diinkubasi dimasukkan kedalam mesin tetas, telur diinkubasi selama lebih kurang 21 hari. Peneropongan pertama dilakukan pada hari ke- 5 untuk penentuan telur fertil dan infertil. Telur fertil ditunjukkan dengan adanya pembuluh darah menyerupai jaring laba-laba dengan bintik ditengah, sedangkan telur infertil dikeluarkan dari mesin tetas. Dari 315 butir telur ayam Kampung yang ditetaskan, diperoleh telur fertil sebanyak 255 dan telur yang menetas sebanyak 174.

Telur yang menetas diberi tanda menggunakan kertas label dan ditimbang setelah bulu DOC kering (Okatama et al., 2018) untuk mendapatkan bobot tetas. Ayam dipelihara mulai dari DOC sampai umur 12 minggu. Luas kandang yang digunakan adalah $4 \times 3 \times 1,8 \mathrm{~m}$ untuk 100 ekor ayam yang dilengkapi dengan tempat pakan, tempat minum serta lampu sebagai penerangan. Pakan dan minum diberikan secara adlibitum. Pengukuran bobot badan dilakukan setiap minggu dan pengukuran tubuh dilakukan setiap 4 minggu, dimana ayam yang diukur diberi tanda pada bagian kaki umur 0 sampai 4 minggu dan pada sayap umur 4 sampai 12 minggu.

\section{Peubah}

Peubah yang diamati dalam penelitian ini yaitu:

1. Bobot telur (BT) diperoleh dari penimbangan telur dengan menggunakan timbangan digital (g).

2. Panjang telur (PT) didapatkan dari pengukuran panjang telur dengan menggunakan jangka sorong $(\mathrm{mm})$.

3. Lingkar telur (LiT) didapatkan dengan mengukur lingkaran telur menggunakan pita ukur (mm).

$$
\text { LeT }=\frac{\text { lingkar } \text { telur }}{6,28} \times 2
$$

4. Lebar telur (LeT) didapatkan dengan mengukur lebar telur dengan rumus.

5. Volume telur dapat diukur dengan menggunakan rumus

$$
\text { Volume telur }=\sum \pi \mathrm{x} \frac{d \times 2}{4} \times t
$$

6. Bobot DOC, bobot yang diperoleh dari hasil penimbangan anak unggas yang menetas setelah bulu anak unggas tersebut kering (Lestari et al., 2013).

7. Bobot badan (BB), diukur dengan cara menimbang ayam dengan timbangan digital (g).

8. Pertambahan bobot badan (PBB), didapatkan cara menghitung selisih akhir dengan selisih awal berat ayam Kampung.

$\mathrm{PBB}=\mathrm{BB}$ akhir (g/minggu) - $\mathrm{BB}$ awal (g/minggu)

9. Panjang paruh (PP) diukur dari pangkal rahang atas sampai ujung pangkal rahang atas, dengan menggunakan jangka sorong digital ( $\mathrm{mm}$ ).

10. Lebar paruh (LP) diukur pada bagian tengah paruh menggunakan jangka sorong digital (mm).

11. Panjang kepala (PL) diukur dari pangkal paruh hingga kepala bagian belakang, menggunakan jangka sorong digital $(\mathrm{mm})$.

12. Tinggi kepala (TK) diukur pada bagian kepala yang paling tinggi dengan menggunakan jangka sorong digital ( $\mathrm{mm}$ ).

13. Lebar dada (LD) Pengukuran lebar dada diperoleh dengan mengukur jarak dari tulang sternum bagian kiri hingga bagian kanan (yang paling lebar) menggunakan jangka sorong digital ( $\mathrm{mm}$ ).

14. Panjang dada (PD) Pengukuran panjang dada (sternum) dilakukan dari depan dada ke belakang menggunakan jangka sorong digital (mm)

15. Panjang tibia (PTi) diukur dari patela sampai ujung tibia diukur dengan menggunakan jangka sorong digital ( $\mathrm{mm}$ ).

16. Panjang shank (PS) diukur sepanjang tulang tarsometatarsus (shank) menggunakan jangka sorong digital ( $\mathrm{mm}$ ).

17. Panjang jari ketiga (PJK) diukur dari pangkal sampai ujung jari ketiga, diukur menggunakan jangka sorong digital ( $\mathrm{mm}$ ).

18. Jaraktulang pubis (JTP) diukur menggunakan jangka sorong digital ( $\mathrm{mm}$ ).

19. Lingkar kepala (LiK) diukur pada bagian 
tertinggi kepala dengan menggunakan pita ukur (cm dikonversi ke $\mathrm{mm}$ ).

20. Lingkar leher (LiL) diukur dengan pita pengukur di sekitar leher (mm).

21. Panjang leher (PL) diukur dari vertebra serviks pertama sampai vertebra serviks terakhir menggunakan jangka sorong digital (mm).

22. Panjang tubuh bagian atas (PTA) diukur dari ujung paruh sampai pangkal ekor menggunakan pita pengukur ( $\mathrm{cm}$ dikonversi ke $\mathrm{mm}$ ).

23. Panjang sayap (PjS) diukur dari tulang humerus sampai ujung falang menggunakan pita pengukur (cm dikonversi ke $\mathrm{mm}$ ).

24. Lingkar dada (LiD) diukur f menggunakan pita pengukur ( $\mathrm{cm}$ dikonversi ke $\mathrm{mm}$ ).

25. Panjang tubuh bawah (PTB) diukur dari pangkal dada sampai pangkal tulang kemaluan dengan jarak menggunakan pita pengukur ( $\mathrm{cm}$ dikonversi ke $\mathrm{mm}$ ).

26. Lingkar tibia (LiT) melingkarkan pita pengukur di pada tibia ( $\mathrm{cm}$ dikonversi ke $\mathrm{mm}$ ).

27. Lingkar shank (LiS) di sekitar pita pengukur di tengah tulang tarsometatarsus (shank) (cm dikonversi ke $\mathrm{mm}$ ).

28. Tinggi punggung (TPu) diukur dari bagian bawah ayam sampai bagian atas kepala menggunakan meteran ( $\mathrm{cm}$ dikonversi ke $\mathrm{mm})$.

\section{Analisis Data}

\section{Uji beda rata-rata (Uji-t)}

Uji-t adalah uji beda rata-rata yang digunakan untuk melihat perbedaan rata-rata ukuranukuran telur, bobot telur, bobot DOC, bobot badan dan pertambahan bobot badan antara ayam Kampung jantan dan ayam Kampung betina.

\section{Analisis regresi}

Analisis Regresi merupakan analisis untuk melihat hubungan antara variabel A dengan variabel B. Analisis regresi linear berganda digunakan untuk melihat hubungan antara ukuran-ukuran telur dengan bobot telur. Analisis regresi parsial digunakan untuk melihat hubungan antara ukuran-ukuran telur dengan bobot telur dan hubungan bobot DOC dengan bobot badan 4, 8, dan 12 minggu. Rumus regresi linear berganda dan parsial:

$$
\mathrm{Y}=\mathrm{b}_{0}+\mathrm{b}_{1} \mathrm{X}_{1}+\mathrm{b}_{2} \mathrm{X}_{2}+\mathrm{b}_{3} \mathrm{X}_{3}+\cdots+\mathrm{b}_{19} \mathrm{X}_{19}
$$

Keterangan:

$\mathrm{Y}=$ Bobot telur/Bobot DOC

$\mathrm{b}_{0}=$ Konstanta

$\mathrm{b}_{1}=$ Koefisien regresi dari ukuran telur (X2)

$\mathrm{b}_{2}=$ Koefisien regresi dari bobot badan(X3)

$\mathrm{b}_{3,4,5,6, \ldots .}=\ldots \ldots . .\left(\mathrm{X}_{3,4,5,6 \ldots . .}\right)$

\section{Analisis Korelasi}

Analisis korelasi digunakan untuk melihat seberapa besar keeratan hubungan ukuranukuran telur dengan bobot telur dan bobot DOC terhadap, bobot badan dan pertambahan bobot badan dihitung berdasarkan rumus menurut Paiman (2019) sebagai berikut:

Keterangan:

$r_{x y}$

$$
\mathrm{r}_{\mathrm{xy}}=\frac{n \sum x_{i} y_{i}-\left(\Sigma x_{i}\right)\left(y_{i}\right)}{\sqrt{\left\{n \Sigma x_{1}^{2}-\left(\Sigma x_{i}\right)^{2} \Re\left\{n \sum y_{2}^{1}-\left(\Sigma y_{1}\right)^{2}\right\}\right.}}=
$$

Korelasi Pearson

$\mathrm{x}=$ Ukuran telur/bobot DOC

$\mathrm{y}=$ Bobot telur/bobot badan

Pengolahan data dibantu dengan menggunakan perangkat lunak statistik yaitu Minitab versi 18.

\section{Analisis komponen utama}

Analisis komponen utama adalah analisis yang digunakan untuk melihat perbedaan penciri ukuran atau penentu bentuk antara ukuranukuran tubuh ayam Kampung jantan dan betina.

$$
Y j=a 1_{j} X_{1}+a 2_{j} X_{2}+a 3_{j} X_{3}+\cdots+a 7_{j} X_{7}
$$

Keterangan:

$\mathrm{Y}_{\mathrm{j}} \quad=$ komponen utama ke-j $(\mathrm{j}=1,2 ; 1=$ ukuran, 2 = bentuk)

$\mathrm{X}_{1,2,3 \ldots}=$ peubah ke $1,2,3 \ldots .7$

$a_{i, 2,2,3, j, . .}=$ vektor eigen variable ke-i $(1,2,3, \ldots .7)$ dan komponen utama ke $\mathrm{j}$

\section{HASIL DAN PEMBAHASAN}

\section{Bobot Telur dan Ukuran Telur}

Berdasarkan Tabel 2. rataan bobot telur panjang telur, lingkar telur, lebar telur, dan volume telur ayam Kampung jantan maupun betina pada penelitian ini lebih tinggi dibandingkan penelitian (Herlina, La \& Muhammad., 2016) yang menyatakan bahwa rata-rata bobot telur ayam Kampung yaitu 42,7 g. Hasil pengukuran lebar telur pada panelitian ini lebih tinggi 
Tabel 2. Rataan bobot telur dan ukuran telur dan bobot telur ayam Kampung jantan dan betina (g)

\begin{tabular}{lcc}
\hline \multicolumn{1}{c}{ Parameter } & \multicolumn{2}{c}{ Ayam Kampung } \\
\hline Jantan & Betina \\
Bobot telur & $44,64 \pm 1,97^{\mathrm{a}}$ & $43,65 \pm 0,90^{\mathrm{b}}$ \\
Panjang telur & $51,62 \pm 2,47^{\mathrm{a}}$ & $50,10 \pm 1,22^{\mathrm{b}}$ \\
Lingkar telur & $127,91 \pm 2,70^{\mathrm{a}}$ & $124,65 \pm 1,59^{\mathrm{b}}$ \\
Lebar telur & $40,74 \pm 0,80^{\mathrm{a}}$ & $39,70 \pm 0,50^{\mathrm{b}}$ \\
Volume telur & $3297,99 \pm 2,23^{\mathrm{a}}$ & $3123,37 \pm 107,18^{\mathrm{b}}$ \\
\hline abSuperskrip yang berbeda pada & baris yang sama \\
berbeda nyata $(\mathrm{P}<0,05)$
\end{tabular}

dibandingkan penelitian (Suhardi, 2013) yang menyatakan bahwa rataan lebar telur ayam lokal adalah 34,99 $\pm 2,03 \mathrm{~mm}$ dan lebar telur IPB D-1 G7 sebesar 38,02 $\pm 3,05$ mm (Habiburahman, Darwati, Sumantri, \& Rukmiasih, 2020). Panjang telur hasil penelitian ini sedikit lebih tinggi dibandingkan dengan penelitian Yayu, La, \& Amiluddin (2020) yang menyatakan bahwa ayam Kampung di Tongkuno memiliki panjang telur yaitu sebesar $49,1 \pm 0,32 \mathrm{~mm}$ dan Tongkuno Selatan sebesar $47,2 \pm 0,37 \mathrm{~mm}$.

Hasil uji beda rata-rata (Uji-t) menunjukan bahwa rataan bobot telur, panjang telur, lingkar telur, lebar telur, dan volume telur ayam Kampung jantan berbeda nyata $(\mathrm{P}<0,05)$ lebih tinggi dibandingkan dengan bobot telur, panjang telur, lingkar telur, lebar telur, dan volume telur ayam Kampung betina. Hal ini diduga karena telur yang menghasilkan DOC ayam Kampung jantan memiliki komponen albumen dan yolk telur yang lebih banyak dibanding telur yang menghasilkan DOC betina, sehingga telur yang menghasilkan DOC jantan menjadikan bobot telur yang lebih berat dan ukuran-ukuran telur yang lebih besar dibandingkan dengan telur yang menghasilkan DOC betina. Hasil tersebut sesuai dengan pendapat (Yuniarinda et al., 2019) yang menyatakan bahwa bobot telur yang berat memiliki komponen albumen dan yold telur yang lebih banyak dibanding telur yang kecil. Telur yang lonjong dan luas memiliki komposisi internal telur yang lebih tinggi sehingga bobot telur menjadi lebih berat dan bobot tetas tinggi.

\section{Bobot Badan Ayam Kampung}

Rataan bobot badan ayam Kampung jantan dan betina umur DOC, 4 minggu, 8 minggu, dan 12 minggu disajikan pada Tabel 3.
Tabel 3. Rataan bobot badan ayam Kampung jantan dan betina $(\mathrm{g})$

\begin{tabular}{lcc}
\hline \multirow{2}{*}{$\begin{array}{c}\text { Umur } \\
\text { Bobot }\end{array}$} & \multicolumn{2}{c}{ Ayam Kampung } \\
\cline { 2 - 3 } & Jantan & Betina \\
\hline DOC & $30,48 \pm 1,22^{\mathrm{a}}$ & $28,88 \pm 1,16^{\mathrm{b}}$ \\
4 minggu & $330,91 \pm 28,89^{\mathrm{a}}$ & $318,41 \pm 19,95^{\mathrm{b}}$ \\
8 minggu & $692,16 \pm 36,98^{\mathrm{a}}$ & $670,76 \pm 21,30^{\mathrm{b}}$ \\
12 minggu & $1134,51 \pm 72,17^{\mathrm{a}}$ & $1091,32 \pm 66,83^{\mathrm{b}}$ \\
\hline abSuperskrip yang berbeda pada & baris yang sama \\
berbeda nyata $(\mathrm{P}<0,05)$ &
\end{tabular}

Berdasarkan Tabel 3. hasil penelitian ini lebih rendah dibandingkan dengan penelitian Puteri, Gushairiyanto, \& Depison (2020) yang menyatakan bahwa bobot DOC ayam KUB sebesar 34,20 $\pm 3,09 \mathrm{~g}$, dan ayam Sentul sebesar $33,85 \pm 2,53$ g. Hasil penelitian ini lebih tinggi dibandingkan dengan penelitian Irmaya, Depison \& Gushairiyanto (2021) yang menyatakan bahwa bobot DOC, bobot badan umur 4, 8, dan 12 minggu ayam Kampung secara berurutan adalah 26,38 g, 224, 68 g, 605,53 g, dan 1.030,30 g. Putri, Gushairiyanto, \& Depison (2020) menyatakan bahwa bobot badan ayam Kampung umur 8 minggu adalah $605,53 \pm 80,01$ g. Eriko, Jatmiko \& Nur (2016) meyatakan bahwa ayam Kampung pada umur 12 minggu memiliki bobot badan ayam Kampung yaitu 1.030,60 g.

Hasil penelitian ini lebih tinggi dibandingkan dengan penelitian Wardono et al. (2014) yang menyatakan bahwa ayam Kampung memiliki berat DOC 28,41 g/ekor. Irmaya et al. (2021) menyatakan berat badan umur 4 minggu adalah 224,68 g, menunjukkan hasil lebih tinggi dibandingkan Mariandayani, Solihin, \& Sulandari (2013) yang menyatakan bahwa bobot badan umur 8 minggu ayam Kampung adalah 358,75 g. Eriko et al. (2016) Menyatakan bahwa ayam Kampung pada umur 12 minggu memiliki bobot badan ayam Kampung betina yaitu 899,5 g.

Hasil uji beda rata-rata menunjukan bahwa rataan bobot badan umur DOC, 4 minggu, 8 minggu, dan 12 minggu ayam Kampung jantan berbeda nyata $(\mathrm{P}<0,05)$ lebih tinggi dibandingkan rataan bobot badan ayam Kampung betina. Hal ini diduga karena pengaruh hormonal gen hormone pertumbuhan $(\mathrm{GH})$, sehingga menyebabkan bobot badan ayam jantan lebih tinggi dibandingkan bobot badan ayam betina. Hal ini diduga karena adanya pengaruh hormone testosterone 


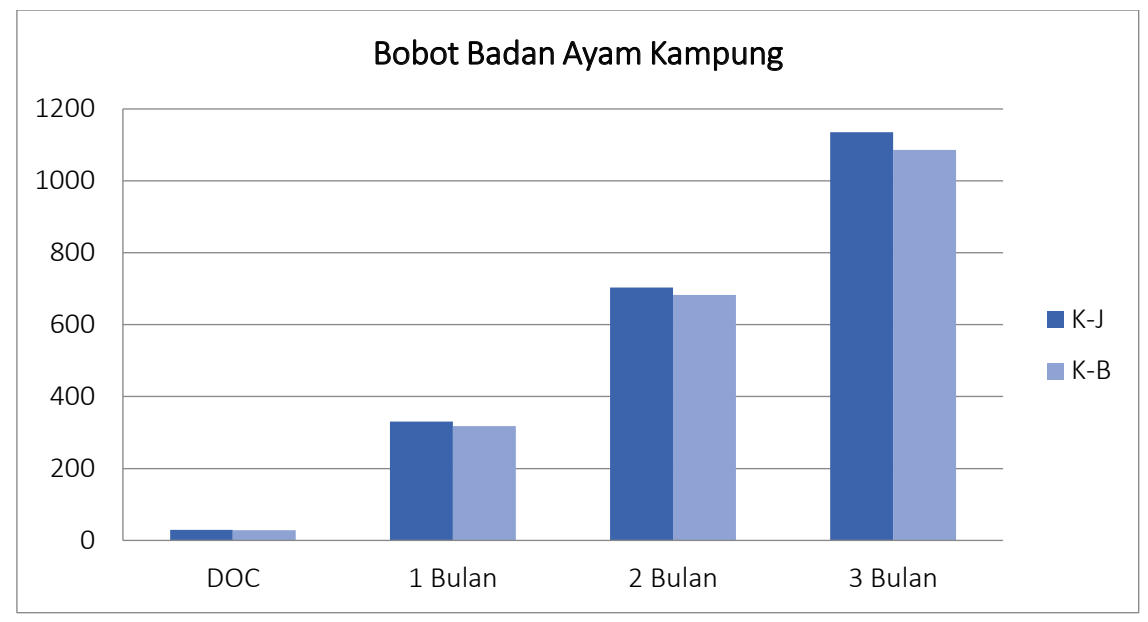

Gambar 1. Grafik bobot badan ayam Kampung

sehingga menyebabkan bobot badan ayam jantan lebih tinggi dibandingkan bobot badan ayam betina. Pagala, La \& Sri (2019) ayam jantan memiliki hormon pengatur pertumbuhan yang lebih tinggi dibandingkan betina. Bobot badan ayam jantan jauh lebih tinggi daripada betina sebagai akibat dari adanya hormone testoteron yang berfungsi sebagai steroid androgen yakni pengatur pertumbuhan. Selanjutnya menurut Pagala, Achmad, Rusli, \& Hamdan (2018) bahwa secara genetik pertumbuhan dikendalikan oleh sejumlah gen salah satunya yaitu gen hormone pertumbuhan, pada ayam jantan gen hormon pertumbuhan mengontrol sifat produksi lebih tinggi dibandingkan ayam betina.

\section{Pertambahan Bobot Badan Ayam Kampung}

Rataan pertambahan bobot badan ayam Kampung jantan dan betina umur DOC, 4 minggu, 8 minggu, dan 12 minggu disajikan pada Tabel 4 .

Berdasarkan Gambar 2, rataan pertambahan bobot badan ayam Kampung baik jantan maupun betina pada penelitian ini lebih tinggi dibandingkan dengan penelitian Kestaria, Nur, \& Malik (2016) yang menyatakan bahwa

Tabel 4. Rataan pertambahan bobot badan ayam Kampung jantan dan betina $(\mathrm{g})$

\begin{tabular}{lcc}
\hline $\begin{array}{l}\text { Pertambahan } \\
\text { bobot badan }\end{array}$ & Jantan & Betina \\
\hline DOC - 4 minggu & $300,43 \pm 26,92^{\mathrm{a}}$ & $289,53 \pm 18,90^{\mathrm{b}}$ \\
4 - 8 minggu & $361,26 \pm 20,53^{\mathrm{a}}$ & $352,34 \pm 13,55^{\mathrm{b}}$ \\
8 -12 minggu & $442,34 \pm 41,08^{\mathrm{a}}$ & $420,57 \pm 51,88^{\mathrm{b}}$ \\
\hline
\end{tabular}

${ }^{\text {ab }}$ uperskrip yang berbeda pada baris yang sama berbeda nyata $(\mathrm{P}<0,05)$ pertambahan bobot badan ayam Kampung umur DOC 4 minggu adalah 225,30 g dan umur 4 sampai 8 minggu 322,93 g. Irmaya et al. (2021) menyatakan bahwa pertambahan bobot badan umur 8 sampai 12 minggu adalah $372,87 \pm 76,31$ g.

Rataan pertambahan bobot badan ayam Kampung tertinggi dicapai pada umur 8 sampai 12 minggu. Hal ini terjadi karena pada umur muda ternak ayam akan mengalami kenaikan bobot badan dan akan mengalami penurunan pada saat ternak menuju proses dewasa kelamin. Hal ini sesuai dengan pendapat Agustina, Iriyanti, \& Mugiyono (2013) yang menyatakan bahwa masa percepatan pertumbuhan terjadi sebelum ternak mengalami pubertas (dewasa kelamin) dan mengalami perlambatan pada saat menuju proses dewasa kelamin. Pada umur 12 hingga 20 minggu akan terjadi penurunan laju pertumbuhan (Trisiwi, 2017).

Hasil uji beda rata-rata pertambahan bobot badan DOC sampai bobot badan umur 12 minggu ayam Kampung jantan berbeda nyata $(\mathrm{P}<0,05)$ lebih tinggi dibandingkan dengan ayam Kampung betina. Perbedaan hasil yang diperoleh tersebut diduga adanya perbedaan hormon pertumbuhan, dimana hormon pertumbuhan (growth hormone) ayam Kampung jantan lebih tinggi dibandingkan ayam Kampung betina. Selain dipengaruhi oleh faktor hormon perbedaan bobot badan antara ayam Kampung jantan dan Kampung betina tersebut diduga bisa terjadi oleh faktor lain yang tidak teramati. 


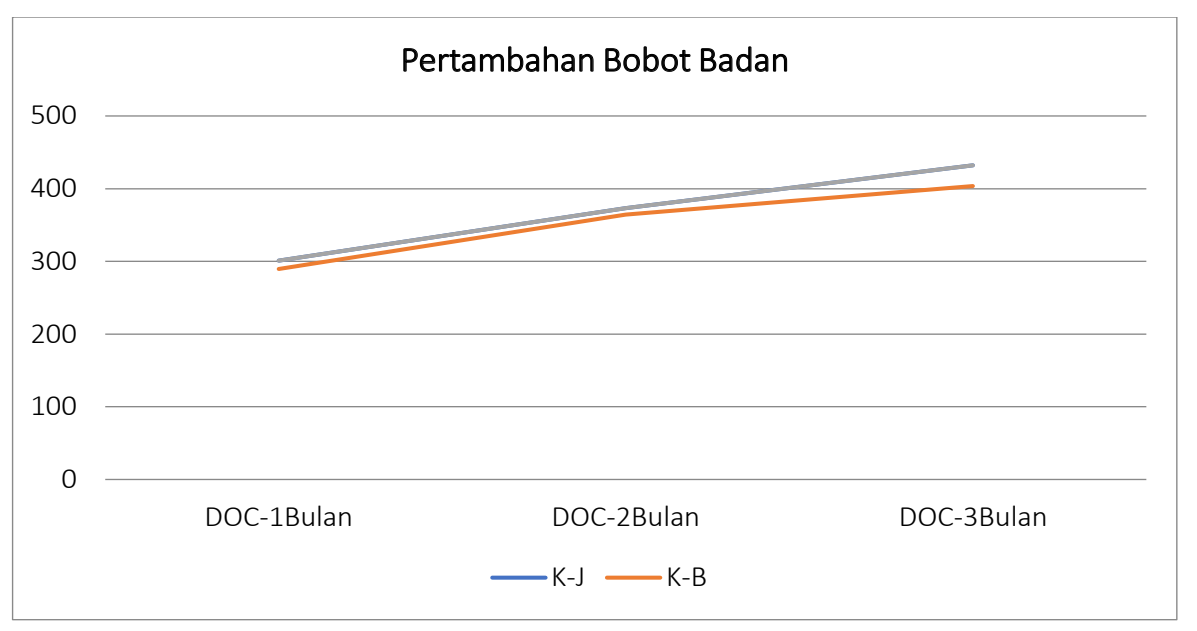

Gambar 2. Pertambahan bobot badan ayam Kampung

\section{Regresi Ukuran-Ukuran Telur dengan Bobot Telur}

Hasil regresi antara ukuran-ukuran telur dengan bobot telur ayam Kampung baik jantan maupun betina disajikan pada Tabel 5 .

Berdasarkan tabel 5. hasil ini menunjukkan setiap kenaikan $1 \mathrm{~cm}$ ukuran-ukuran telur akan memepengaruhi kenaikan bobot telur ukuran ukuran telur akan berdampak terhadap bobot telur ternak tersebut.

Hasil uji regresi ini menunjukan bahwa rataan panjang telur, lingkar telur, dan volume telur diduga memiliki hubungan yang positif terhadap bobot telur. Okatama et al. (2018) menyatakan bahwa ukuran-ukuran telur dengan bobot telur memiliki hubungan bersifat positif dan signifikan. Berdasarkan hasil tersebut diduga bahwa panjang telur, lingkar telur, lebar telur dan volume telur dapat dijadikan pedoman sebagai seleksi dini pada ternak ayam Kampung.

\section{Korelasi Ukuran Telur dengan Bobot Telur}

Nilai korelasi antara ukuran ukuran telur bobot telur ayam Kampung baik jantan maupun betina disajikan pada Tabel 6 .

Berdasarkan Tabel 6. hasil ini menunjukan bahwa terdapat korelasi positif antara ukuranukuran telur dengan bobot telur serta didapatnya hubungan yang signifikan antara ukuran-ukuran telur dengan bobot telur. Berdasarkan hasil tersebut korelasi yang terjadi antara bobot telur dengan ukuran-ukuran telur adalah hubungan yang berbanding lurus yang berarti semakin besar bobot telur maka ukuran-ukuran telur semakin besar. Hal ini sesuai dengan Ustadha, Sutopo \& Sumeidiana (2016) yang menyatakan bahwa bobot DOC ternak ayam dipengaruhi oleh bobot telur, dimana semakin besar bobot telur maka bobot DOC semakin besar.

Secara parsial nilai korelasi tertinggi antara ukuran- ukuran telur dengan bobot telur

Tabel 5. Persamaan regresi ukuran telur dengan bobot telur ayam Kampung

\begin{tabular}{lll}
\hline Uraian & \multicolumn{1}{c}{ Variabel } & \multicolumn{1}{c}{ Persamaan } \\
\hline Jantan & Umum & Bt $=-28,77+0,0189$ Panjang Telur + 0,5173 Lingkar Telur + 0,001937 volume telur \\
& Bt - pt & Bt $=17,82+5,300$ Panjang Telur \\
& Bt- lit & Bt $=-39,74+0,660$ Lingkar Telur \\
& Bt- let & Bt $=-39,74+2,075$ Lebar telur \\
& Bt- vt & Bt $=20,42+0,007$ volume telur \\
Betina & Umum & Bt $=-6,34+0,2126$ Panjang Telur + 0,2822 Lingkar Telur + 0,001333 volume telur \\
& Bt- pt & Bt $=16,53+0,541$ Panjang Telur \\
& Bt- lit & Bt $=-13,83+0,461$ Lingkar Telur \\
& Bt- let & Bt $=-13,63+1,447$ Lebar telur \\
& Bt- vt & Bt $=22,99+0,006$ volume telur \\
\hline
\end{tabular}


Tabel 6. Korelasi antara ukuran-ukuran telur dengan bobot telur ayam Kampung jantan dan betina

\begin{tabular}{llcccc}
\hline \multirow{2}{*}{ Uraian } & \multirow{2}{*}{ Vaiabel } & \multicolumn{2}{c}{ Jantan } & \multicolumn{2}{c}{ Betina } \\
\cline { 3 - 6 } & & $\mathrm{R}$ & $\mathrm{r}^{2}$ & $\mathrm{r}$ & $\mathrm{r}^{2}$ \\
\hline Ayam & Umum & 0,85 & 0,722 & 0,756 & 0,572 \\
Kampung & Bt-Pt & 0,671 & 0,45 & 0,742 & 0,55 \\
& Bt-Lit & 0,913 & 0,833 & 0,822 & 0,675 \\
& Bt-Let & 0,913 & 0,833 & 0,822 & 0,675 \\
\cline { 2 - 6 } & Bt-Vt & 0,828 & 0,686 & 0,792 & 0,627 \\
\hline
\end{tabular}

yang menghasilkan DOC jantan dan betina ayam Kampung adalah lingkar telur (LiT). Berdasarkan hasil tersebut diduga bahwa lingkar telur (LiT) dapat dijadikan pedoman dalam pendugaan bobot DOC.

\section{Regresi Bobot DOC dengan Bobot Badan}

Hasil regresi bobot DOC dengan bobot badan ayam disajikan pada Tabel 7 .

Tabel 7. Regresi bobot DOC, 4 minggu, 8 minggu, dan 12 minggu ayam Kampung

\begin{tabular}{lll}
\hline Uraian & Variabel & Persamaan \\
\hline Jantan & $\begin{array}{l}\text { DOC - } \\
\text { minggu }\end{array}$ & $-58,9+12,79$ Bobot DOC \\
& $\begin{array}{l}\text { DOC - } 8 \\
\text { minggu }\end{array}$ & $224,9+15,33$ Bobot DOC \\
& $\begin{array}{l}\text { DOC - } 12 \\
\text { minggu }\end{array}$ & $291,3+27,66$ Bobot DOC \\
Betina & $\begin{array}{l}\text { DOC - } 4 \\
\text { minggu }\end{array}$ & $-134,7+15,69$ Bobot DOC \\
& $\begin{array}{l}\text { DOC - } 8 \\
\text { minggu }\end{array}$ & $214,2+15,81$ Bobot DOC \\
& $\begin{array}{l}\text { DOC - 12 } \\
\text { minggu }\end{array}$ & $-205+44,89$ Bobot DOC \\
\hline
\end{tabular}

Berdasarkan Tabel 7, nilai koefisien regresi tersebut menggambarkan bahwa setiap kenaikan bobot DOC akan mempengaruhi kenaikan bobot badan sebesar koefisiennya, semakin besar bobot DOC maka bobot badan ayam Kampung akan semakin besar. Nilai koefisien regresi ayam Kampung jantan lebih tinggi dibandingkan ayam Kampung betina. Hal ini diduga karena adanya pengaruh perbedaan jenis kelamin antara ayam Kampung jantan dan betina, sesuai dengan pendapat Kostaman \& Sutedi (2019) yang menyatakan bahwa jenis kelamin akan mempengaruhi bobot badan umur faktor yang 4 , 8, dan 12 minggu dan jenis kelamin jantan lebih tinggi dibandingkan betina.
Di sisi lain pada sistem pemeliharan yang dilakukan antara ayam Kampung jantan dan betina tidak dilakukan perbedaaan sistem pemeliharaan, seperti pemberian pakan, kualitas pakan, serta dipelihara pada lingkungan yang sama. Berdasarkan hasil uji regresi antara ayam Kampung jantan dan betina sampai umur 12 minggu dapat diketahui bahwa bobot DOC memiliki hubungan yang positif dan signifikan terhadap bobot badan umur 4 minggu, 8 minggu, dan 12 minggu.

\section{Korelasi Bobot DOC dengan Bobot Badan}

Hasil korelasi bobot DOC dengan bobot badan ayam disajikan pada Tabel 8 .

Tabel 8. Korelasi bobot DOC, 4 minggu, 8 minggu, dan 12 minggu ayam Kampung jantan dan betina

\begin{tabular}{llcccc}
\hline \multirow{2}{*}{ Uraian } & Vaiabel & \multicolumn{2}{c}{ Jantan } & \multicolumn{2}{c}{ Betina } \\
\cline { 3 - 6 } & & $\mathrm{r}$ & $\mathrm{r}^{2}$ & $\mathrm{r}$ & $\mathrm{r}^{2}$ \\
\hline Ayam & DOC - 4 & 0,936 & 0,876 & 0,911 & 0,83 \\
Kampung & $\begin{array}{l}\text { minggu } \\
\text { DOC - 8 } \\
\text { minggu }\end{array}$ & 0,879 & 0,773 & 0,86 & 0,74 \\
& $\begin{array}{l}\text { DOC - 12 } \\
\text { minggu }\end{array}$ & 0,811 & 0,658 & 0,779 & 0,607 \\
\hline
\end{tabular}

Berdasarkan Tabel 8. hasil ini diduga adanya perbedaan hormon antara ayam Kampung jantan dan betina, sesuai dengan pendapat Pagala et al. (2018) yang menyatakan bahwa pada ayam jantan gen hormon pertumbuhan mengontrol sifat produksi lebih tinggi dibandingkan ayam betina.

Secara parsial nilai korelasi tertinggi DOC umur4 minggu, 8 minggu, 12 minggu adalah bobot umur DOC 4 minggu, berdasarkan hasil ini bobot umur 4 minggu dapat digunakan sebagai pendugaan bobot DOC pada ayam Kampung baik jantan maupun betina. Sesuai dengan pendapat Wardono et al. (2014) yang menyatakan bahwa nilai korelasi positif tinggi diperoleh antara hubungan berat DOC dengan berat badan saat umur 4, 6 dan 8 minggu. Hasil ini menunjukan bahwa bobot DOC memiliki keeratan hubungan yang signifikan dengan bobot 4 minggu dibandingkandengan bobot 8 dan 12 minggu . Artinya bobot 4 minggu dapat digunakan sebagai pendugaan bobot DOC ayam Kampung baik jantan maupun betina. 


\section{Ukuran-Ukuran Tubuh Ayam Kampung}

Rataan ukuran-ukuran tubuh ayam Kampung Jantan dan betina disajikan pada Tabel 9.

Tabel 9. Ukuran-ukuran tubuh ayam Kampung jantan dan betina

\begin{tabular}{lcc}
\hline Ukuran & \multicolumn{2}{c}{ Kampung } \\
Tubuh & Jantan & Betina \\
\hline PP (mm) & $29,43 \pm 0,77^{\mathrm{a}}$ & $25,20 \pm 0,64^{\mathrm{b}}$ \\
PK (mm) & $36,26 \pm 2,02^{\mathrm{a}}$ & $34,29 \pm 1,56^{\mathrm{b}}$ \\
LP (mm) & $7,18 \pm 0,41^{\mathrm{a}}$ & $6,23 \pm 0,28^{\mathrm{b}}$ \\
TK (mm) & $29,99 \pm 1,45^{\mathrm{a}}$ & $28,27 \pm 1,15^{\mathrm{b}}$ \\
LiK (mm) & $112,98 \pm 0,48^{\mathrm{a}}$ & $110,76 \pm 0,39^{\mathrm{b}}$ \\
PL (mm) & $133,12 \pm 0,61^{\mathrm{a}}$ & $127,81 \pm 0,71^{\mathrm{b}}$ \\
LiL (mm) & $91,63 \pm 0,38^{\mathrm{a}}$ & $88,83 \pm 0,37^{\mathrm{b}}$ \\
PSa (mm) & $218,90 \pm 1,30^{\mathrm{a}}$ & $194,68 \pm 0,88^{\mathrm{b}}$ \\
PTA (mm) & $267,83 \pm 0,79^{\mathrm{a}}$ & $241,94 \pm 0,71^{\mathrm{b}}$ \\
PTB (mm) & $276,13 \pm 1,21^{\mathrm{a}}$ & $255,38 \pm 0,82^{\mathrm{b}}$ \\
TPu (mm) & $285,93 \pm 2,64^{\mathrm{a}}$ & $266,83 \pm 1,29^{\mathrm{b}}$ \\
PD (mm) & $130,31 \pm 5,45^{\mathrm{a}}$ & $118,98 \pm 5,02^{\mathrm{b}}$ \\
LD (mm) & $63,73 \pm 2,22^{\mathrm{a}}$ & $59,85 \pm 2,38^{\mathrm{b}}$ \\
LiD (mm) & $277,93 \pm 0,84^{\mathrm{a}}$ & $258,83 \pm 0,77^{\mathrm{b}}$ \\
PS (mm) & $78,66 \pm 3,50^{\mathrm{a}}$ & $71,01 \pm 2,90^{\mathrm{b}}$ \\
LiS (mm) & $43,82 \pm 0,33^{\mathrm{a}}$ & $41,34 \pm 0,18^{\mathrm{b}}$ \\
PTi (mm) & $123,42 \pm 8,60^{\mathrm{a}}$ & $117,43 \pm 5,52^{\mathrm{b}}$ \\
LiTi (mm) & $100,41 \pm 0,63^{\mathrm{a}}$ & $96,17 \pm 0,55^{\mathrm{b}}$ \\
PJK (mm) & $55,47 \pm 4,88^{\mathrm{a}}$ & $50,84 \pm 2,71^{\mathrm{b}}$ \\
JTP (mm) & $13,13 \pm 0,26^{\mathrm{a}}$ & $14,18 \pm 0,47^{\mathrm{b}}$ \\
\hline
\end{tabular}

${ }^{a b}$ Superskrip yang berbeda pada baris yang sama berbeda nyata $(\mathrm{P}<0,05)$, Keterangan : $\mathrm{PP}=$ Panjang Paruh, LP = Lebar Paruh, PK = Panjang Kepala, TK $=$ Tinggi Kepala,$\quad$ LiK $=$ Lingkar Kepala, $\mathrm{PL}=$ Panjang Leher, LiL = Lingkar Leher, PSa = Panjang Sayap, $\mathrm{PPu}=$ Panjang Punggung, $\mathrm{TPu}=$ Tinggi Punggung, $\mathrm{PD}=$ Panjang Dada, $\mathrm{LD}=$ Lebar Dada, $\mathrm{PS}=$ Panjang Shank, LiS = Lingkar Shank, PTi = Panjang Tibia, LiTi = Lingkar Tibia, $\mathrm{PJK}=$ Panjang Jari Ketiga, JTP = Jarak Tulang Pubis,

Berdasarkan Tabel 9. bahwa ayam yang memiliki rataan ukuran tubuh tertinggi yaitu ayam Kampung jantan, artinya kerangka ukuran tubuh Kampung jantan lebih besar dibandingkan dengan Kampung betina. Hal ini terjadi karena Kampung jantan memiliki bobot yang lebih tinggi dibandingkan dengan Kampung betina. Menurut Stanggang, Hasnudi, \& Hamdan (2016) semakin besar ukuran kerangka tubuh suatu individu maka ukuran tubuhnya juga akan besar. Ukuran tubuh yang besar memiliki karkas yang besar. Wahyudi, Ciptadi, \& Budiarto (2017) menyatakan bahwa semakin besar ukuran tubuh memiliki karkas yang besar maka bobot badan ternak akan semakin besar.

Berdasarkan Tabel 9. di atas hasil uji beda rata-rata ukuran-ukuran tubuh ayam Kampung jantan berbeda nyata $(\mathrm{P}<0,05)$ lebih tinggi dibandingkan dengan ayam Kampung betina. Perbedaan rataan ukuran tubuh ini diduga karena adanya pengaruh genetik, sehingga menurut Putri et al. (2020) apabila keragaman kondisi lingkungan tidak ada, maka perbedaan ukuran tubuh tersebut disebabkan oleh keragaman genetik.

Persamaan ukuran tubuh, bentuk tubuh, keragaman total dan nilai eigen ayam Kampung jantan dan betina disajikan pada Tabel 10 .

Berdasarkan Tabel 10. vektor eigen tertinggi pada persamaan ukuran tubuh pada ayam Kampung baik jantan maupun betina yaitu lingkar dada. Ayam Kampung berjenis kelamin jantan tidak sesuai dengan pendapat Rahmatullah et al. (2018) yang menyatakan bahwa ayam jantan memiliki keragaman dalam morfometrik pada bagian lebar dada, yang menunjukan bahwa lebar dada menjadi penentu ukuran tubuh sedangkan penentu ukuran tubuh ayam betina dipengaruhi oleh lingkar dada. Menurut Mahmudi, Priyanto \& Jakaria (2019) bahwa perbedaan ukuran maupun bentuk tubuh pada galur ternak disebabkan oleh adanya perbedaan faktor genetik. Vektor eigen tertinggi pada persamaaan bentuk tubuh pada Kampung jantan adalah panjang lebar dada, Kampung betina panjang tubuh atas.

Hasil ini dapat digunakan sebagai salah satu cara dalam pertimbangan pemuliaan ternak dan sebagai pertimbangan kebijakan pemurnian ayam Kampung pada masa yang akan datang. Ukuran-ukuran tubuh dapat dimanfaatkan untuk menduga gambaran bentuk tubuh sebagai penciri khas suatu bangsa tertentu (Putri et al., 2020). Hasil penelitian ini menunjukkan bahwa lingkar dada (LD) dapat dijadikan sebagai parameter seleksi dalam meningkatkan skor tubuh dan sebagai pertimbangan kebijakan pemurnian ayam Kampung.

\section{KESIMPULAN}

Hubungan ukuran telur dengan bobot telur dan bobot DOC dengan bobot badan berbentuk 
Tabel 10. Persamaan ukuran dan bentuk tubuh dengan keragaman total dan nilai eigen pada Ayam Kampung jantan dan betina

\begin{tabular}{|c|c|c|c|c|c|c|}
\hline Jenis & & & & Persamaan & KT (\%) & $\lambda$ \\
\hline \multirow[t]{4}{*}{$\begin{array}{l}\text { Ayam } \\
\text { Kampung }\end{array}$} & \multirow[t]{2}{*}{ Jantan } & $\begin{array}{l}\text { Ukuran } \\
\text { Tubuh }\end{array}$ & $=$ & $\begin{array}{l}\text { 0,251 PP + 0,167 LP + 0,062 PK + 0,251 TK + 0,191 } \\
\mathrm{LiK}+0,253 \mathrm{PL}+0,235 \mathrm{LiL}+0,252 \mathrm{PSa}+0,245 \mathrm{PTa} \\
+0,252 \mathrm{PTb}+0,243 \mathrm{TPu}+0,243 \mathrm{PD}+0,244 \mathrm{LD}+ \\
0,255 \mathrm{LiD}+0,246 \mathrm{PS}+0,023 \mathrm{LiS}+0,245 \mathrm{PTi}+0,168 \\
\mathrm{LiTi}+0,240 \mathrm{PJK}+0,223 \mathrm{JTP}\end{array}$ & 74,2 & 14,845 \\
\hline & & $\begin{array}{l}\text { Bentuk } \\
\text { Tubuh }\end{array}$ & $=$ & $\begin{array}{l}-0,075 \mathrm{PP}+0,154 \mathrm{LP}+-0,028 \mathrm{PK}+-0,050 \mathrm{TK}+ \\
-0,378 \mathrm{LiK}+-0,018 \mathrm{PL}+-0,240 \mathrm{LiL}+-0,019 \mathrm{PSa} \\
+0,097 \mathrm{PTa}+-0,026 \mathrm{PTb}+0,076 \mathrm{TPu}+0,110 \mathrm{PD} \\
+0,196 \mathrm{LD}+0,079 \mathrm{LiD}+0,090 \mathrm{PS}+-0,764 \mathrm{LiS}+ \\
0,061 \mathrm{PTi}+-0,274 \mathrm{LiTi}+0,152 \mathrm{PJK}+0,022 \mathrm{JTP}\end{array}$ & 6,9 & 1,372 \\
\hline & \multirow[t]{2}{*}{ Betina } & $\begin{array}{l}\text { Ukuran } \\
\text { Tubuh }\end{array}$ & $=$ & $\begin{array}{l}0,236 \mathrm{PP}+0,183 \mathrm{LP}+0,232 \mathrm{PK}+0,238 \mathrm{TK}+0,237 \\
\mathrm{LiK}+0,233 \mathrm{PL}+0,235 \mathrm{LiL}+0,224 \mathrm{PSa}+0,151 \mathrm{PTa} \\
+0,223 \mathrm{PTb}+0,235 \mathrm{TPu}+0,224 \mathrm{PD}+0,236 \mathrm{LD}+ \\
0,240 \mathrm{LiD}+0,238 \mathrm{PS}+0,213 \mathrm{LiS}+0,23 \mathrm{PTi}+0,23 \\
\mathrm{LiTi}+0,238 \mathrm{PJK}+0,17 \mathrm{JTP}\end{array}$ & 82,4 & 16,481 \\
\hline & & $\begin{array}{l}\text { Bentuk } \\
\text { Tubuh }\end{array}$ & $=$ & $\begin{array}{l}-0,075 \mathrm{PP}+-0,25 \mathrm{LP}+0,142 \mathrm{PK}+-0,123 \mathrm{TK}+-0 ., 49 \\
\mathrm{LiK}+-0,022 \mathrm{PL}+-0,119 \mathrm{LiL}+-0,153 \mathrm{PSa}+0,681 \\
\mathrm{PTa}+0,01 \mathrm{PTb}+-0,128 \mathrm{TPu}+0,031 \mathrm{PD}+0,068 \mathrm{LD} \\
+-0,03 \mathrm{LiD}+0,001 \mathrm{PS}+-0,225 \mathrm{LiS}+-0,037 \mathrm{PTi}+ \\
0,068 \mathrm{LiTi}+-0,03 \mathrm{PJK}+0,558 \mathrm{JTP}\end{array}$ & 4,3 & 0,865 \\
\hline
\end{tabular}

Keterangan: PP = Panjang Paruh, LP = Lebar Paruh, PK = Panjang Kepala, TK = Tinggi Kepala, LiK = Lingkar Kepala, PL = Panjang Leher, LiL = Lingkar Leher, PSa = Panjang Sayap, PPu = Panjang Punggung, $\mathrm{TPu}=$ Tinggi Punggung, PD = Panjang Dada, LD = Lebar Dada, PS = Panjang Shank, LiS = Lingkar Shank, PTi = Panjang Tibia, LiTi = Lingkar Tibia, PJK = Panjang Jari Ketiga, JTP = Jarak Tulang Pubis.

linier dan bernilai positif. Penciri ukuran tubuh ayam Kampung jantan, betina adalah lingkar dada. Penciri bentuk ayam Kampung jantan lebar dada dan ayam Kampung betina panjang tubuh atas.

\section{UCAPAN TERIMA KASIH}

Ucapan terimaksih penulis sampaikan kepada Fakultas Peternakan, Universitas Jambi serta semua pihak yang telah membantu untuk penyelesaian artikel ini.

\section{DAFTAR PUSTAKA}

Agustina, D., Iriyanti, N. \& Mugiyono, . S. (2013). Pertumbuhan dan konsumsi pakan pada berbagai jenis itik lokal betina yang pakannya di suplementasi probiotik. Jurnal Ilmiah Peternakan, 1(2), 691-698. Retrieved from http://jos.unsoed.ac.id/ index.php/jip/article/view/639

Badaruddin, R., Syamsuddin, ., Astuty, F., \& Pagala, M. A. (2017). Performa penetasan telur ayam hasil persilangan ayam Bangkok dengan ayam Ras Petelur. Jurnal Ilmu
Dan Teknologi Peternakan Tropis, 4(2), 1. https://doi.org/10.33772/jitro.v4i2.3225

Eriko, Jatmiko, \& Nur, H. (2016). Pengaruh penggantian sebagian ransum komersial dengan dedak padi terhadap performa ayam Kampung. Peternakan Nusantara, 2(1), 27-33.

Habiburahman, R., Darwati, S., Sumantri, C., \& Rukmiasih. (2020). Produksi telur dan kualitas telur ayam IPB D-1 G7 serta pendugaan nilai ripitabilitasny. Jurnal IImu Produksi Dan Teknologi Hasil Peternakan, 8(2), 97-101. https://doi.org/10.29244/ jipthp.8.2.97-101

Herlina, La O. N., \& Muhammad, A. P. (2016). Bobot tetas dan fertilitas pada ayam Kampung dan hasil persilangannya JITRO, 3(3), 32-37. https://doi.org/http://dx.doi. org/10.33772/jitro.v3i3.2566

Irmaya, D., Depison, D., \& Gushairiyanto, G. (2021). Quantitative characteristic of Indonesian native chickens at the age of 4 months. Livestock and Animal Research, 19(1), 108. https://doi.org/10.20961/lar.v19i1.43150

Kestaria, Nur, H., \& Malik, B. (2016). Pengaruh substitusi pakan komersil dengan tepung ampas kelapa terhadap performa ayam 
Kampung. Jurnal Peternakan Nusantara, 2(1), 43-48.

Kostaman, T. \& Sutedi, E. (2019). Performan ayam KUB umur 0-12 minggu di program bekerja desa Jatiwangi, Kecamatan Pakenjeng, Kabupaten Garut. 718-724. https:// doi.org/10.14334/pros.semnas.tpv2019-p.718-724

Lestari, E. Ismoyowati, \&Sukardi. (2013). Korelasi antara bobot telur dengan bobot tetas dan perbedaan susut bobot pada telur entok (Cairrina moschata) dan itik (Anas plathyrhinchos). Jurnal Ilmiah Peternakan, 1(April), 163-169. Retrieved from http:// jos.unsoed.ac.id/index.php/jip/article/ view/566

Mahmudi, M., Priyanto, R., \& Jakaria, J. (2019). Karakteristik morfometrik sapi Aceh, sapi PO dan sapi Bali berdasarkan analisis komponen utama (AKU). Jurnal IImu Produksi Dan Teknologi Hasil Peternakan, 7(1), 35-40. https://doi.org/10.29244/ jipthp.7.1.35-40

Mariandayani, Hariani, N. S., Dedy.D. S., Sumantri, S. \&C. (2013). Keragaman fenotipik dan pendugaan jarak genetik pada ayam Lokal dan ayam Broiler menggunakan analisis morfologi (phenotypic variation and estimation genetic distance between local chicken and broiler chicken using morphological analysis). Jurnal Veteriner, 14(4), 475-484. Retrieved from https://ojs. unud.ac.id

Nuraini, Hidayat, Z. \&Yolanda, K. (2018). Performa bobot badan akhir, bobot karkas serta persentase karkas ayam Merawang pada keturunan dan jenis kelamin yang berbeda. Sains Peternakan, 16(2), 69-73. https:// doi.org/10.20961/sainspet.v16i2.23236

Okatama, M. S., Maylinda, S.. \&Nurgiartiningsih, V. M. A. (2018). Hubungan bobot telur dan indeks telur dengan bobot tetas itik Dabung di Kabupaten Bangkalan. Ternak Tropika Journal Of Tropical Animal Production, 19(1), 1-8. https://doi.org/10.21776/ ub.jtapro.2018.019.01.1

Pagala, M. A., Aku, A. S., Badaruddin, R., \& Has, H. (2018). Karakteristik fenotip dan genotip gen gh (growth hormon) pada ayam Tolaki. Jurnal Ilmu Dan Teknologi Peternakan Tropis, 5(2), 1. https://doi.org/10.33772/ jitro.v5i3.4705

Paiman. (2019). Analisi korelasi dan regresi ilmuilmu peternakan.Yogyakarta: UPY Press.

Puteri, N. I., Gushairiyanto, and D. (2020). Growth patterns, body weight, and morphometric of kub chicken, sentul chicken and arab chicken. Buletin Peternakan, 44(3),
67-72. https://doi.org/10.21059/ buletinpeternak.v44i3.57016

Putri, A. B. S. R. N., Gushairiyanto, G., \& Depison, D. (2020). Bobot badan dan karakteristik morfometrik beberapa galur ayam Lokal. Jurnal Ilmu Dan Teknologi Peternakan Tropis, 7(3), 256. https://doi.org/10.33772/jitro. v7i3.12150

Rahmatullah, S. N. a., \& , Z. Efendia , H. Mayulua, F. A. dan A. S. (2018). Perbandingan morfometrik ayam lokal kalimantan timur berdasarkan pendekatan analisis diskriminan. Peternakan Tropika Peternakan Tropika, 6(3), 817-828. Retrieved from https://simdos.unud. ac.id/uploads/file_penelitian_1_ a62e1b18443e312ea393947017b283.pdf

Rajab. (2013). Hubungan bobot telur dengan fertilitas, daya tetas, dan bobot anak ayam kampung.Agrinimal,3(2),56-60. Retrieved from https://ejournal.unpatti.ac.id

Sitanggang, E. N., Hasnudi, \& Hamdan. (2016). Kampung , Ayam Bangkok, Ayam Katai , Ayam Birma, Ayam Bagon. Jurnal Peternakan Integratif, 3(2), 167-189. Retrieved from https://www.researchgate. net/publication/298313660\%0A

Suhardi. (2013). Struktur dan kualitas telur ayam lokal khas dayak bagi pengembangan dan pelestarian plasma nutfah ternak unggas. Jurnal Peternakan, 10(2), 67-73. https:// doi.org/http://dx.doi.org/10.24014/jupet. v10i2.2321

Trisiwi, H. F. (2017). Pengaruh level protein pakan pada masa pertumbuhan terhadap penampilan pada awal peneluran ayam betina hasil persilangan ayam kampung jantan dan ayam ras petelur betina. Jurnal Ilmu Dan Teknologi Hasil Ternak, 12(2), 61-68. https://doi.org/10.21776/ ub.jitek.2017.012.02.1

Ustadha, C. Sutopo, \& I. S. K. (2016). Pengaruh perbedaan bobot telur terhadap bobot tetas dan mortalitas ayam kedu jengger merah dan ayam kedu jengger hitam. Agromedia, 34(2), 65-71. https://doi.org/https://doi. org/10.47728/ag.v34i2.177

Wahyudi. E., Gatot. C., \& Agus, B. (2017). Studi kasus tingkat pemotongan kambing berdasarkan jenis kelamin, kelompok umur dan bobot karkas di tempat pemotongan hewan kota malang. J. Ternak Tropika, 18(1), 69-76. https://doi.org/10.16285/j. rsm.2007.10.006

Wardono, H. P., Sugihono, C., Kusnadi, H. \& S. (2014). Korelasi antara beberapa kriteria peubah produksi pada ayam buras. Prosiding Seminar Nasional "Inovasi 
Teknologi Pertanian Spesifik Lokasi," 577585. Retrieved from http://kalsel.litbang. pertanian.go.id

Yayu A., La O. N., \& Amaluddin. I. (2020). Karakteristik telur ayam Kampung pada pemeliharaan tradisional di Kecamatan Tongkuno dan Tongkuno Selatan. Jurnal Ilmiah Peternakan Halu Oleo, 2(3), 295299. Retrieved from http://ojs.uho.ac.id/ index.php/jipho/article/view/16886

Yuniarinda, C., Edy, K., \&Sri. K., \& Program. (2019). Pengaruh bobot telur terhadap daya tetan dan bobot tetas itik Magelang generasi ke-4 di satuan kerja itik Banyubiru - Ambarawa. Jitp, 7(2), 1-4. Retrieved from https://journal.unhas.ac.id/index.php/ peternakan/article/view/6646 